\title{
Changes of discharge voltage of plate-type sodium sulfur batteries in the early charge/discharge cycles
}

\author{
Seong-In Kim*, Heon-Tae Kim***, Hee-Lack Choi**, San-Su-Dae Lim***, Kee-Deok Yang***, Jin- \\ Hyung Beum*** and Chang-Sam Kim*, ${ }^{*}$ \\ *Center for Energy Convergence, Korea Institute of Science and Technology, Seoul 136-791, Korea \\ **Department of Materials Science and Engineering, Pukyong National University, Busan 608-739, Korea \\ ***R\&BD Dept. Finetech Co., Ltd., Daejeon 305-510, Korea
}

(Received June 12, 2014)

(Revised July 1, 2014)

(Accepted July 11, 2014)

Abstract The sodium-sulfur batteries which operate at $350^{\circ} \mathrm{C}$ have been mainly used in the field of energy storage system. This batteries consist of liquid sodium anode, sulfur cathode and $\beta$ "-alumina solid electrolyte. The conditioning process for stabilization of the batteries is essential since the cells show considerable fluctuation of discharge voltage at the beginning of discharge/charge cycles. It is found that one of the reasons of the fluctuation is the gradual change of contact area between molten sodium and solid electrolyte.

Key words Sodium sulfur battery, ESS, $\beta^{\prime \prime}$-alumina, Overpotential, Contact area

\section{평판형 나트륨 유황 전지의 초기 충방전시 방전전압 변화}

\author{
김성인*, 김헌태***, 최희락**, 임산수대***, 양기덕***, 범진형***, 김창삼*, \\ *한국과학기술연구원 에너지융합연구센터, 서울, 136-791 \\ ***부경대학교 재료공학과, 부산, 608-739 \\ ***화인테크 연구개발부, 대전, 305-510 \\ (2014년 6월 12일 접수) \\ (2014년 7월 1일 심사완료) \\ (2014년 7월 11일 게재확정)
}

요 약 나트륨 유황 전지는 $350^{\circ} \mathrm{C}$ 이상의 고온에서 작동하는 대용량 전지로 에너지 저장 시스템에 주로 사용된다. 전 지는 음극 액체 나트륨과 양극 액체 유황 그리고 고체 전해질 베타 알루미나( $\beta^{\prime \prime}$-alumina)로 구성되어 있다. 이 전지는 초기 충방전 사이클에서 상당한 전압변화를 보이기 때문에 전지의 안정화를 위해 컨디셔닝 과정이 필요하다. 실험 결과 전지 전 압 변화의 주요한 원인 중의 하나가 액체 나트륨과 고체 전해질과의 접촉 면적이 변하기 때문인 것을 알았다.

\section{1. 서 론}

최근 전세계적으로 무분별한 화석연료 사용으로 인한 환경문제에 대한 우려로 재생가능 에너지 발전 시스템과 에너지 저장 시스템(energy storage system, ESS) 개발 에 많은 연구가 이루어 지고 있다[1-3]. 그 중 높은 이 론 에너지 밀도, 높은 에너지 효율, 그리고 높은 수명 때문에 나트륨 유황 전지(sodium sulfur battery, NAS

${ }^{\dagger}$ Corresponding author

Tel: +82-2-958-5483

Fax: +82-2-958-5479

E-mail: cskim@kist.re.kr battery)는 대용량 에너지 저장 시스템용으로 일본과 중 국에서 제조되고 있다 $[4,5]$. 그러나 우리나라에서는 전 해질 제조 기술이 확립되지 않아서 수입한 전해질을 사 용하여 단전지를 조립하는 단계에 머물러 있다.

나트륨 유황 전지는 $350^{\circ} \mathrm{C}$ 에서 작동하는 고온 대용량 전지로 음극에 용융 나트륨, 양극에 용융 유황 그리고 고체 전해질인 베타 알루미나( $\beta^{\prime \prime}$-alumina)로 구성되며, 다음과 같은 간단한 전기 화학 반응을 통하여 작동한다 [6].

$$
\begin{aligned}
& \text { Anode: } 2 \mathrm{Na}-2 \mathrm{e}^{-} \leftrightarrow 2 \mathrm{Na}^{+} \\
& \text {Cathode: } \mathrm{xS}+2 \mathrm{Na}^{+}+2 \mathrm{e}^{-} \leftrightarrow \mathrm{Na}_{2} \mathrm{~S}_{\mathrm{x}}(\mathrm{x}=3 \sim 5)
\end{aligned}
$$


Cell reaction: $2 \mathrm{Na}+\mathrm{xS} \leftrightarrow \mathrm{Na}_{2} \mathrm{~S}_{\mathrm{x}}(\mathrm{x}=3 \sim 5)$

나트륨 유황 전지의 작동 전압은 작동 온도 $350^{\circ} \mathrm{C}$ 에 서 $1.78 \sim 2.076 \mathrm{~V}$ 를 나타내며 위의 반응에 따른 전지의 에너지 밀도는 $760 \mathrm{Wh} / \mathrm{kg}$ 이다[4, 6].

나트륨 유황 전지는 음극의 용융 나트륨과 양극의 용 융 유황의 반응으로 작동하여 다른 전지보다 전기 화학 적 반응이 비교적 간단하나 셀의 구조나 재료 등에 따라 전기화학적 특성에 많은 차이를 나타낸다[4]. 특히 나트 륨 유황 전지의 고체 전해질로 사용되는 $\beta^{\prime \prime}$-알루미나는 전지의 작동과 비용을 결정하는 중요 요소 중 하나이다 [7]. 이번 연구에서는 평판형 나트륨 유황 전지의 초기 충방전시 방전전압 변화에 대하여 알아보았다.

\section{2. 실험방법}

\section{1. 양극}

양극 전극을 이루는 PAN계 카본 펠트(polyacrylonitrile, $\mathrm{PAN}$ )와 활물질 유황(Sigma-Aldrich, $\geq 99.5 \%) 1 \mathrm{~g}$ 을 비 커에 함께 넣고 $150^{\circ} \mathrm{C}$ 로 가열하여 유황을 녹여 카본 펠 트에 주입하였다. 그 후, 용융 유황이 주입된 카본 펠트 를 양극 두께 $(3 \mathrm{~mm})$ 만큼 압축한 상태에서 냉각시켜 용 융 유황을 응고 시켜 카본 펠트의 두께를 양극 두께로 만들었다. 유황이 주입된 카본 펠트는 수분과 공기의 접 촉을 최대한 피하기 위해 진공상태로 보관하였다. Fig. 1(a)는 카본 펠트, (b)는 용융 유황이 주입된 카본 펠트 의 SEM 사진이다.

\section{2. 평판 나트륨 유황 셀 조립}

평판 나트륨 유황 셀을 구성하는 부품(SUS 집전체, 알 루미늄 가스켓, 그리고 금속 $\mathrm{O}$ ring)을 아세톤(Daejung,

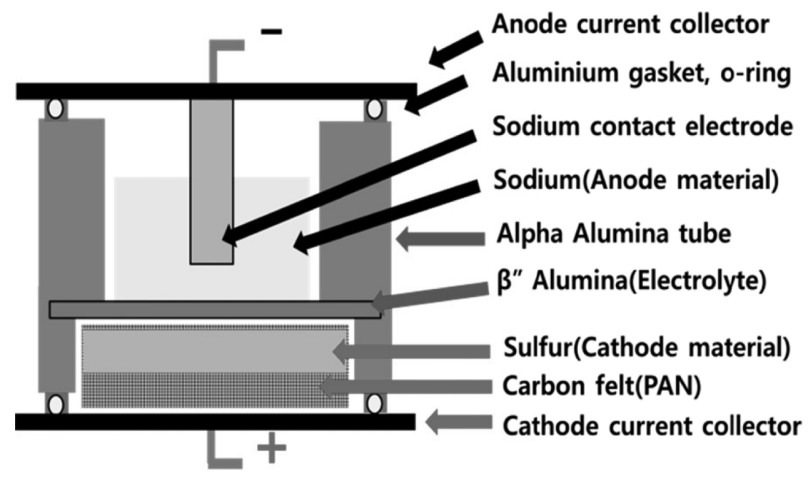

Fig. 2. Schematics of plate-type NAS cell.

$\geq 99.5 \%$ )으로 초음파 세척하고 $80^{\circ} \mathrm{C}$ 오븐에서 24 시간 건조시켜 부품 표면에 남아있는 흡착물과 수분을 제거하 였다. $\alpha$-알루미나 튜브와 $\beta^{\prime \prime}$-알루미나 전해질에 남아 있 는 수분은 음극 활물질인 나트륨과 $\beta^{\prime \prime}$-알루미나의 젖음 성을 악화시킬 뿐만 아니라 나트륨을 산화시키므로[8], $\alpha$-알루미나 튜브와 $\beta^{\prime \prime}$-알루미나 전해질을 접합한 후 진공 포장하여 보관하였다. $\beta^{\prime \prime}$-알루미나 전해질의 저항은 교류 임피던스법으로 측정하였으며[9] 각각 $3.6 \Omega$ 과 $4.5 \Omega$ 로 측정되었다. 전지 조립은 수분과 산소의 농도가 $0.1 \mathrm{ppm}$ 이하인 고순도 $\mathrm{Ar}$ 분위기의 글로브 박스에서 수행하였으 며, Fig. 2는 조립한 평판 나트륨 유황 셀의 단면도이다. 음극 활물질인 나트륨(Sigma Aldrich, $\geq 99.9 \%$ )은 산화 된 표면을 지르코니아 칼로 잘라 내고 표면에 묻어있는 오일을 헥산(Sigma Aldrich, anhydrous, $\geq 99 \%$ )으로 세 척하여 사용하였다.

\section{3. 승온 및 충방전 시험}

조립한 평판 나트륨 유황 셀을 백금선(Pt $100 \%$, $\Phi 0.2)$ 을 사용하여 사이클러와 연결시키고 박스로에 넣어 셀 작동온도인 $350^{\circ} \mathrm{C}$ 로 가열하였다. 상온에서 $150^{\circ} \mathrm{C}$ 까지 는 나트륨과 유황의 녹는점이 이 구간에 있으므로 $0.5^{\circ} \mathrm{C} /$
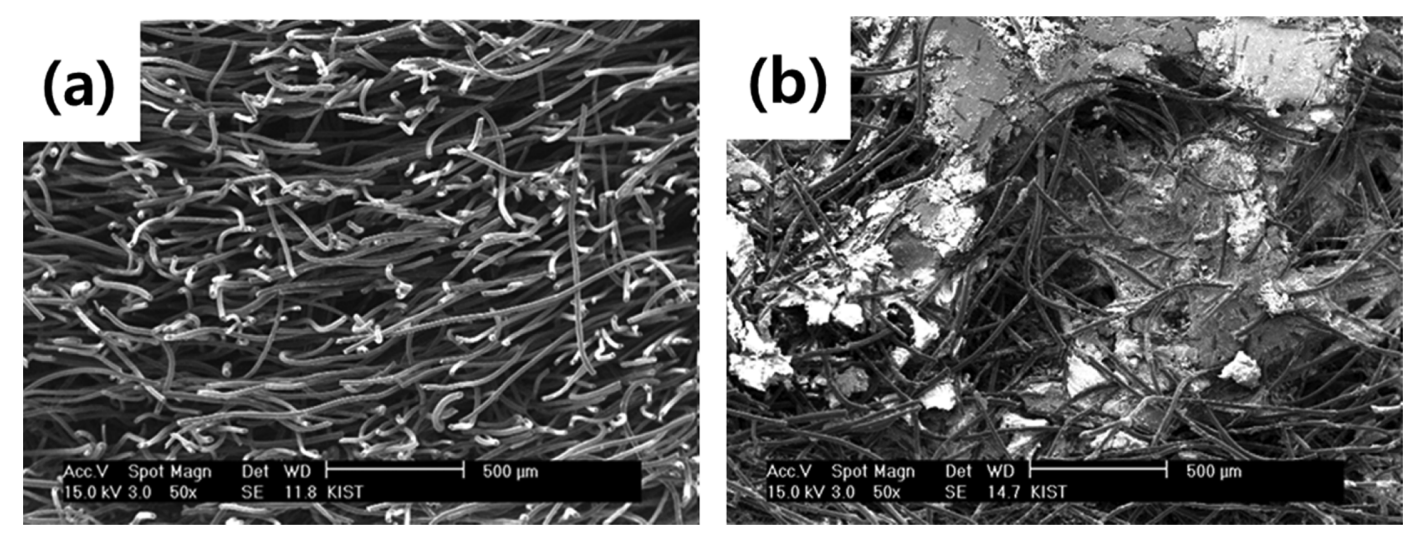

Fig. 1. SEM images of carbon felt; (a) before sulfur impregnation and (b) after sulfur impregnation. 
분의 느린 속도로 승온시켰고, $150^{\circ} \mathrm{C}$ 에서 작동온도인 $350^{\circ} \mathrm{C}$ 까지는 $1^{\circ} \mathrm{C} /$ 분의 속도로 승온시켰다. 그 후 셀이 안정화되도록 180 분 동안 유지시키고 충방전 시험을 진 행하였다.

충방전 시험은 셀 용량을 기준으로 방전심도 $14 \%$ $70 \%$ 범위에서 충방전하였으며, 방전 초기의 일정 전위 를 나타내는 $\mathrm{Na}_{-} \mathrm{Na}_{2} \mathrm{~S}_{5}$ 2-phase 영역에서 셀의 율특성을 측정하였다. 또한, 셀의 이론용량은 다음과 같은 방법으 로 계산하였다.

Cell reaction: $2 \mathrm{Na}+3 \mathrm{~S} \leftrightarrow \mathrm{Na}_{2} \mathrm{~S}_{3}+2 \mathrm{e}$

$1 \mathrm{~mol}$ sulfur $\rightarrow 2 / 3 \mathrm{~mol} \mathrm{e}^{-}$

$1 \mathrm{~g}$ sulfur $=0.03125 \mathrm{~mol}$ sulfur

$2 / 3 \times 0.03125 \mathrm{~mol} \times 96485 \mathrm{C} / \mathrm{mol}$

$$
=2010.10 \mathrm{C}=558 \mathrm{mAh}
$$

\section{3. 결과 및 고찰}

Fig. 3은 전해질 비저항이 $4.5 \Omega \cdot \mathrm{cm}$ 인 Cell 1 과 $3.6 \Omega$. $\mathrm{cm}$ 인 Cell 2의 방전 전류밀도에 따른 방전전압 변화를, Fig. 4는 전류밀도에 따른 과전압의 변화를 나타낸 그래 프이다. 방전 전류밀도가 증가함에 따라 방전전압이 감 소하여 과전압이 증가하였다. 전해질 저항이 상대적으로 높은 Cell 1이 Cell 2에 비해 같은 전류밀도에서 더 큰 과전압을 나타내고 있었다. 전류밀도가 $5 \sim 20 \mathrm{~mA} / \mathrm{cm}^{2}$ 로 낮은 범위에서는 전류밀도 증가에 따라서 과전압이 직선 적으로 증가하였으나, 전류밀도가 $20 \sim 40 \mathrm{~mA} / \mathrm{cm}^{2}$ 에서는 과전압이 직선적으로 증가하지 않고 증가율이 감소하였 다. 전류밀도에 따른 과전압의 변화율은 전해질 저항이 큰 Cell 1이 저항이 작은 Cell 2에 비하여 컸다. 일반적

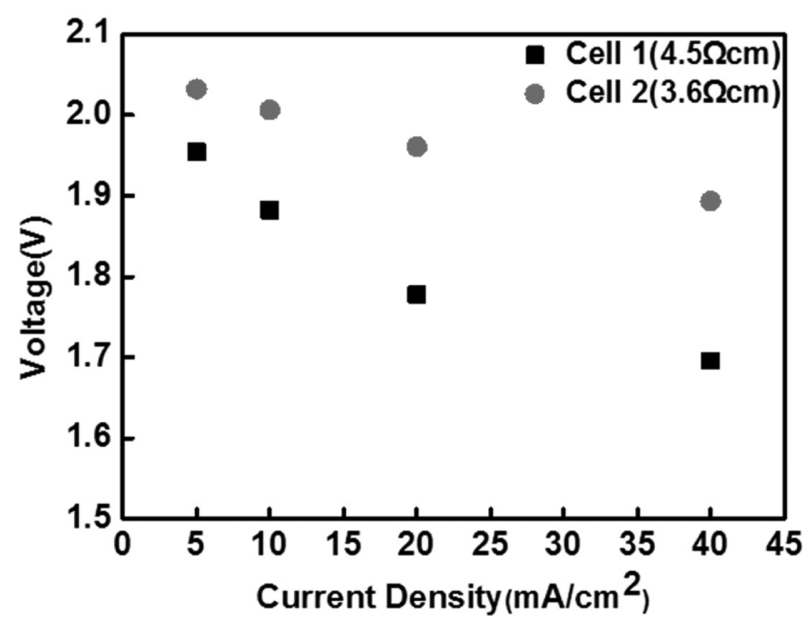

Fig. 3. Discharge voltages of the cells at various current densities.

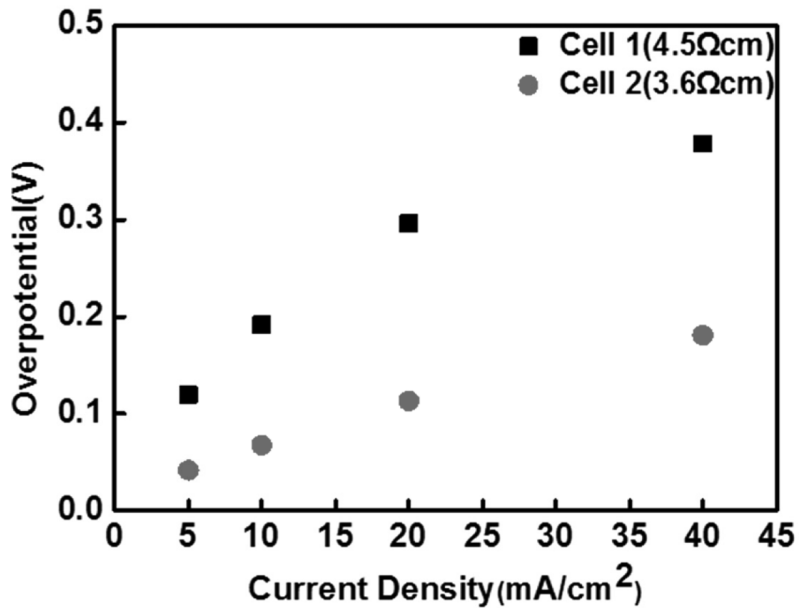

Fig. 4. Discharge overpotential of the cells at various current densities.

으로 이러한 과전압의 증가는 내부 분극의 증가에 기인 한다. 전지에서의 내부 분극은 IR강하로 표현되는 ohmic 분극, 주로 전극 특성과 관련된 활성화 분극, 그리고 전 해질과 활물질 계면에서의 농도 구배에 따른 농도 분극 으로 구분된다[10]. $\beta "$ "알루미나 전해질에 의한 분극은 IR강하로 주파수에 영향을 받지 않으며 전류밀도에 비례 해서 증감한다. 활성화 분극이나 농도 분극은 방전초기 에 생성되는 $\mathrm{Na}_{2} \mathrm{~S}_{5}$ 가 이온 전도성과 전자 전도성이 높 은 물질이기 때문에 과전압 변화에는 영향을 주지 않을 것으로 생각되며, 영향이 있더라도 전류밀도 증가에 따 라서 과전압이 증가하는 방향으로 작용할 것이다. 그러 나, Fig. 4에서는 전류밀도 증가에 따라서 과전압이 정 비례하게 증가하지 않고 과전압 변화율이 감소하는 결과 를 나타내고 있어, 본 실험의 셀에서는 내부 분극 외에 다른 요인이 영향을 주고 있다고 생각되었다.

Fig. 5 는 전해질 저항이 $4.5 \Omega$ 인 Cell 1 을 이론용량의 $14 \sim 70 \%$ 구간에서 방전전류밀도 $40 \mathrm{~mA} / \mathrm{cm}^{2}$, 충전전류밀

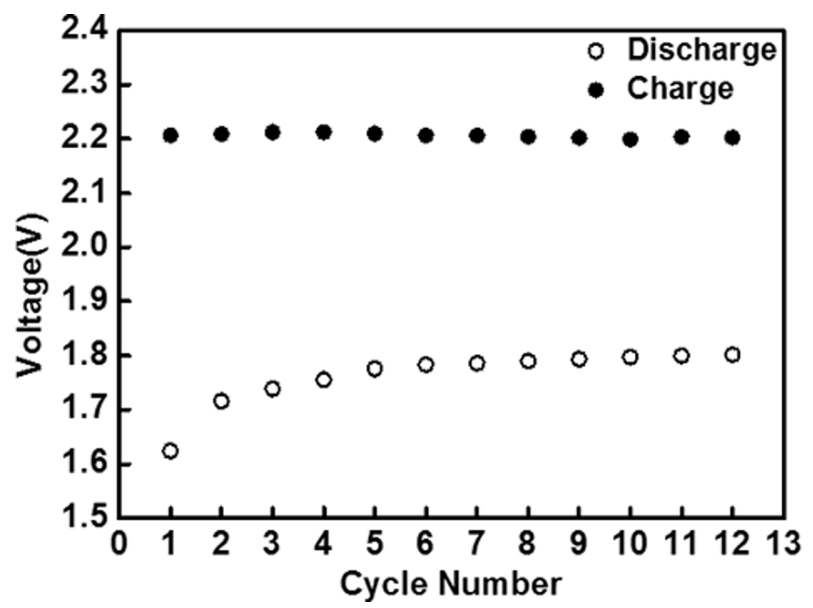

Fig. 5. Discharge and charge voltages of the cells via the number of discharge/charge cycles. 

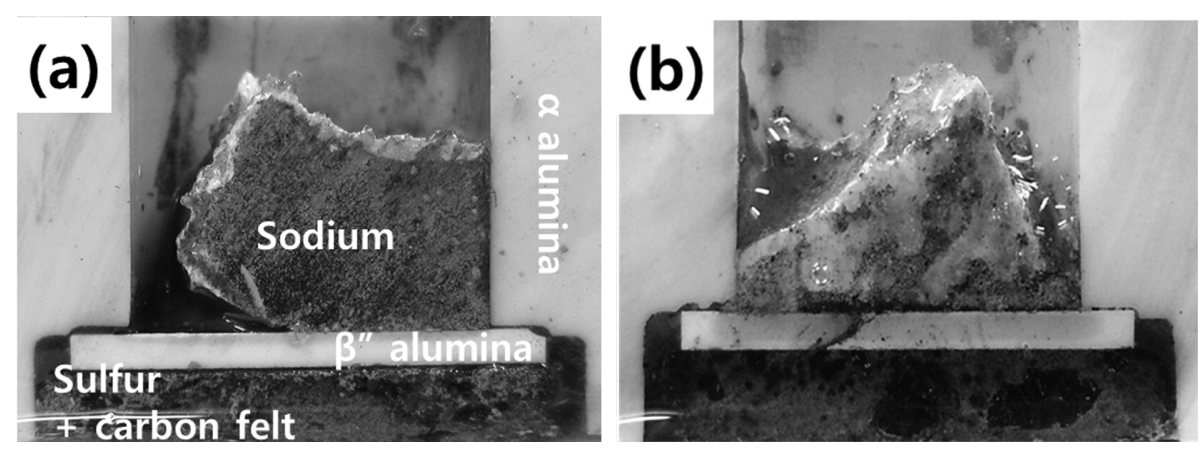

Fig. 6. Cross section of the cells cycled after 2 times (a) and 10 times (b).

도 $30 \mathrm{~mA} / \mathrm{cm}^{2}$ 으로 12 회 충방전하여 방전전압과 충전전 압을 측정한 결과이다. 방전전압은 첫 사이클에서 $1.62 \mathrm{~V}$ 이었으나 두 번째 사이클에서는 $1.72 \mathrm{~V}$ 로 크게 높아졌으 며, 10 사이클까지 지속적으로 증가하여 $1.80 \mathrm{~V}$ 까지 상 승하였다. 결과적으로 10 사이클까지 충방전시 셀의 방 전 과전압이 감소하고 있었다.

사이클이 진행됨에 따라서 과전압이 감소하는 원인들 을 분석하기 위해 2 회와 10 회 사이클이 진행되고 충전 된 상태의 셀을 절단하여 단면을 관찰하였다. Fig. 6의 (a)는 2 회 충방전한 셀이고 (b)는 10 회 충방전한 셀의 절단면 사진으로, 좌우의 흰 부분이 $\alpha$-알루미나 튜브, 튜브 사이를 가로지르는 흰 부분이 $\beta "$-알루미나 전해질, 전해질 위의 덩어리가 나트륨 음극, 전해질 아래 쪽이 카본 펠트, 유황, 그리고 황화나트륨 화합물로 된 양극이 다. Fig. 6(a)를 보면, 음극의 나트륨이 전해질에 완전히 젖지 않고 일부만 접촉하고 있는 것을 볼 수 있다. 반면 Fig. 6(b)는 나트륨이 전해질과 전체적으로 접촉하고 있 는 것을 알 수 있다. 전기화학적 반응이 효과적으로 일 어나는 면적은 양극과 음극이 전해질을 사이에 두고 대 칭을 이루는 면적에서이다. Fig. 6(a)에서와 같이 나트륨 이 전해질과 접촉하지 않은 면이 있으면 이곳에서는 전 기화학반응이 일어나지 않는다. 따라서 이러한 셀에서는 가한 전류밀도보다 더 높은 전류밀도가 전해질에 가해진 것이 된다. 용융 나트륨의 전해질에 대한 젖음성은 셀의 전기화학적 특성에 영향을 주는 요인이다. 용융 나트륨 이 전해질에 젖는 것을 돕기 위해서 전해질에 카본 코팅 하는 방법이 사용되고 있다[11]. 본 실험에서는 나트륨 의 젖음성을 향상하기 위한 코팅을 하지 않았으며, 따라 서 방전 초기에 나트륨이 전해질의 모든 면과 접촉하지 않았다가, 충방전이 반복되면서 나트륨이 음극과 양극을 왕복하면서 조금씩 접촉면적이 늘어난 것으로 생각된다.

Fig. 7은 충방전을 12회 수행한 셀(Cell 3)의 방전 전 류밀도에 따른 방전전압 변화를 측정하여 Fig. 3의 Cell $2(3.6 \Omega \mathrm{cm})$ 와 비교한 결과이다. Fig. 3의 Cell 2 에서는 $40 \mathrm{~mA} / \mathrm{cm}^{2}$ 의 전류밀도에서 $1.77 \mathrm{~V}$ 이었던 방전전압이, 충방전을 12 회 수행한 전지에서는 $1.95 \mathrm{~V}$ 로 상승하여

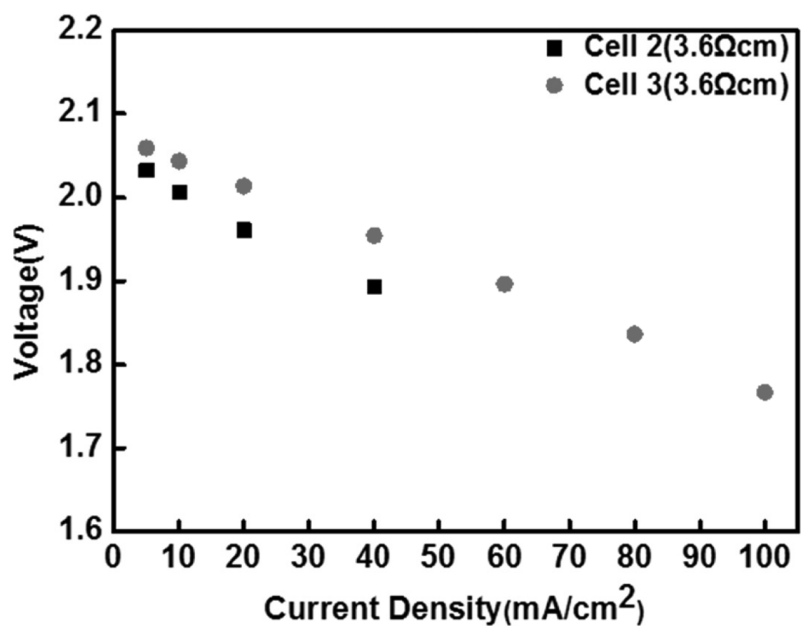

Fig. 7. Discharge voltages of the cells at various current densities.

과전압이 크게 감소하였다. 또한 $100 \mathrm{~mA} / \mathrm{cm}^{2}$ 의 높은 전 류밀도에서도 $1.76 \mathrm{~V}$ 의 전위를 나타내었다. 이 결과에서 충방전 초기에 셀의 방전전압이 변하는 주 이유는 용융 나트륨이 전해질에 완전히 젖지 않은 상태에서 점차적으 로 접촉면적이 늘어나기 때문인 것을 알았다.

\section{4. 결 론}

나트륨 유황 전지의 방전전압은 사이클이 진행되면서 상승하여 10 회에서 안정되었다. 또한 초기 방전시에는 방전전류밀도에 비례하지 않게 과전압이 증가하였다. 충 방전 사이클이 다른 셀을 분해하여 분석한 결과 음극인 나트륨과 전해질의 접촉 면적의 변화가 과전압 변화에 영향을 미치고 있는 주원인의 하나임을 알았다.

\section{감사의 글}

본 연구는 지식경제부 에너지개발사업(“대용량 전력저 장용 고성능, 고안정성 베타알루미나 양산기술 개발", 과 
제번호; 2012T100201533)의 지원으로 수행되었습니다.

\section{References}

[1] B. Dunn, H. Kamath and J.-M. Tarascon, "Electrical energy storage for the grid: A battery of choices", Science 334 (2011) 928.

[2] M.-I. Jeong and C.-J. Choi, "Passivation properties of $\mathrm{SiNx}$ and $\mathrm{SiO} 2$ thin films for the application of crystalline Si solar cells", J. Korean Cryst. Growth Cryst. Technol. 24 (2014) 41.

[3] Inyu Park, "Fabrication of $\mathrm{Sm} 0.5 \mathrm{Sr} 0.5 \mathrm{CoO} 3$ cathode films for intermediate temperature SOFCs by electrostatic spray deposition" J. Korean Cryst. Growth Cryst. Technol. 20 (2010) 69.

[ 4 ] Z. Wen, Y. Hu, X. Wu, J. Han and Z. Gu, "Main challenges for high performance NAS battery: Materials and interfaces", Advanced Functional Materials 23 (2013) 1005.

[ 5 ] Z. Wen, J. Cao, Z. Gu, X. Xu, F. Zhang and Z. Lin,
"Research on sodium sulfur battery for energy storage", Solid State Ionics 179 (2008) 1697.

[6] Z. Yang, J. Zhang, M.C. Kintner-Meyer, X. Lu, D. Choi, J.P. Lemmon and J. Liu, "Electrochemical energy storage for green grid", Chemical Reviews 111 (2011) 3577.

[ 7 ] T. Oshima, M. Kajita and A. Okuno, "Development of sodium-sulfur batteries", International Journal of Applied Ceramic Technology 1 (2004) 269.

[8] L. Viswanathan and A.V. Virkar, "Wetting characteristics of sodium on beta-alumina and on nasicon", Journal of Materials Science 17 (1982) 753.

[9] A. Hooper, "A study of the electrical properties of single-crystal and polycrystalline $\beta$-alumina using complex plane analysis", Journal of Physics D: Applied Physics 10 (1977) 1487.

[10] J.-K. Park, "Principles and applications of lithium secondary battries" (HongRung, Seoul, 2010) p. 19.

[11] Y. Hu, Z. Wen, X. Wu and J. Jin, "Low-cost shape-control synthesis of porous carbon film on $\beta$ "-alumina ceramics for Na-based battery application", Journal of Power Sources 219 (2012) 1. 